\title{
Embryo development and zona-shedding in the ligated oviduct and contralateral uterine horn of non-lactating and lactating Mongolian gerbils (Meriones unguiculatus)
}

\author{
M. L. Norris \\ A.F.R.C. Institute of Animal Physiology, Animal Research Station, 307 Huntingdon Road, \\ Cambridge CB3 OJQ, U.K.
}

\begin{abstract}
Summary. Within the same female, concurrent lactation had no apparent effect on the development and hatching of embryos artificially retained in the oviduct while effectively inhibiting zona shedding and implantation in the contralateral uterine horn. This result is believed due to a specific inhibitor(s) present in the uterine fluid or to physical constriction by the uterus. These extrinsic, maternal factors act either singly or in combination to influence the mature blastocyst.
\end{abstract}

\section{Introduction}

Shedding of the zona pellucida by the mammalian blastocyst is an essential prerequisite for uterine attachment and implantation. Attempts to elucidate the mechanism(s) by which blastocyst activation (see McLaren, 1973) and zona-shedding occur have largely centred on the rat and mouse, particularly with animals exhibiting lactational or experimental delay of implantation.

The Mongolian gerbil (Meriones unguiculatus) is similar to the rat and mouse in that implantation is dependent on ovarian oestrogen $(\mathrm{Wu}, 1975)$ and concurrent lactation induces delayed implantation (Norris \& Adams, 1971; Meckley \& Ginther, 1972). However, the Mongolian gerbil differs from the rat and mouse in that the period of delay is more prolonged (Norris \& Adams, 1981), and the fact that the zona pellucida is retained by the blastocyst throughout most of the delay period (Meckley \& Ginther, 1972) suggests that zona-shedding is a more closely implantation-related event in this species.

Experiments on mammals of various species have shown that the oviduct is able to support normal preimplantation development of the embryo (see Adams, 1973). This report examines the ability of gerbil embryos to develop and hatch in the ligated oviduct and contralateral uterine horn during pregnancies with and without concurrent lactation.

\section{Materials and Methods}

Animals. Mature females from the colony at the Animal Research Station were maintained as described earlier (Norris \& Adams, 1981). On the morning after parturition, mating was confirmed by the presence of spermatozoa in the vaginal smear (=Day 1 post coitum) and litters were either removed $(N=47)$ or adjusted to $5-6$ young $(N=50)$, this number being maintained throughout the experimental period. On Day 2, all females had one oviduct ligated at the utero-tubal junction (Norris \& Rall, 1983) using Armofil No. 1.5 suture material (Armour Pharmaceutical Co. Ltd, Eastbourne, U.K.).

Autopsy procedures. During Days 7-12, 44 non-lactating and 50 lactating females were autopsied and the remaining 3 non-lactating females were autopsied on Day 6. Ovaries, oviducts 
and uteri were removed and the corpora lutea (CL) were counted. In all of the non-lactating females, and in 44 of the lactating females, the ligated oviducts were fragmented in a hollow watch glass containing Dulbecco's phosphate-buffered saline (PBS), pH 7.4 (Dulbecco \& Vogt, 1954). In the absence of visible implantation sites the uterine horns were flushed with PBS, and the oviducal and uterine flushings were immediately searched for embryos with a stereomicroscope. The embryos were morphologically assessed, and some were measured using a Leitz ocular micrometer $(\times 12 \cdot 5)($ E. Leitz Wetzler, Germany) and $\times 40$ objective. Air-dried spreads (Tarkowski, 1966) were made of some blastocysts, stained with $0 \cdot 1 \%$ toluidine blue (G. T. Gurr, High Wycombe, Bucks), and the number of cells counted. Uteri from non-lactating females on Day 8 were bleached and cleared (Orsini, 1962) to confirm the presence of implantations.

The ligated oviducts and contralateral uterine horns were removed from 6 lactating females on Day 12 and immediately fixed in $2.5 \%$ glutaraldehyde in PBS, post-fixed in Bouin's fluid, dehydrated, cleared in cedar wood oil and embedded in paraffin wax. Blocks were serially sectioned at $10 \mu \mathrm{m}$ and stained with Mallory's triple stain.

\section{Results}

Details of the embryos recovered relative to the number of CL present are given in Table 1. Similar oviducal and uterine recovery rates were recorded for non-lactating $(60 \%$ and $89 \%)$ and lactating $(69 \%$ and $86 \%)$ females.

\section{Oviducal blastocysts}

In both groups, loss of the zonae pellucidae first occurred on Day 7 with a steady increase up to Day 12 (see Fig. 1). Highly expanded, zona-intact blastocysts were common and there was considerable variation in the size of blastocysts recovered (Figs $2 \mathrm{a}-\mathrm{c}$ ). Throughout Days $7-12$, the non-lactating females yielded 106 oviducal blastocysts of which $62(58 \%)$ were hatching or hatched. Over the same period the lactating females yielded 122 oviducal blastocysts of which 58 $(47 \%)$ were hatching or hatched. Some empty zonae were recovered from the oviducts (14 from non-lactating females, and 8 from lactating females).

\section{Uterine blastocysts}

In the non-lactating females loss of the zona pellucida first occurred on Day 7 and implantation on Day 8, whereas in the lactating females all blastocysts had an intact zona up to Day 11 , and only 1 out of 15 blastocysts recovered on Day 12 had hatched (see Fig. 1). No empty zonae were observed in the uterine flushings from females of either group. A typical uterine blastocyst in lactational delay is illustrated in Fig. 2(d).

\section{Blastocyst size}

During the period Days 7-12 there was no significant effect of day of pregnancy on the size of zona-intact blastocysts recovered from the ligated oviducts or uterine horns. Measurements made on 94 blastocysts gave mean sizes of $117 \pm 5 \mu \mathrm{m}$ and $115 \pm 5 \mu \mathrm{m}$ for non-lactating and lactating females respectively. A mean size of $106 \pm 1 \mu \mathrm{m}$ was recorded for 76 blastocysts recovered from the uteri of lactating females. For lactating females having blastocysts recovered from the ligated oviduct and the contralateral uterine horn an analysis of variance showed that the oviducal blastocysts were on average larger than those from the uterus $(P<0.01)$. 


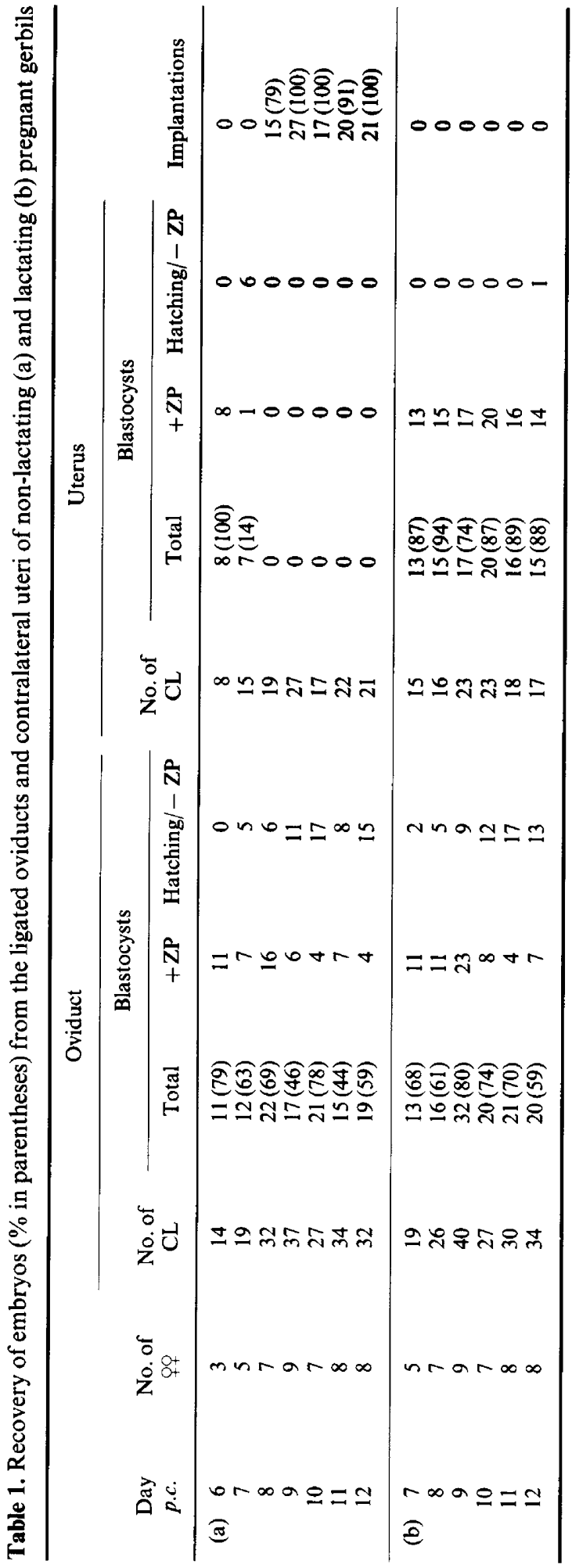




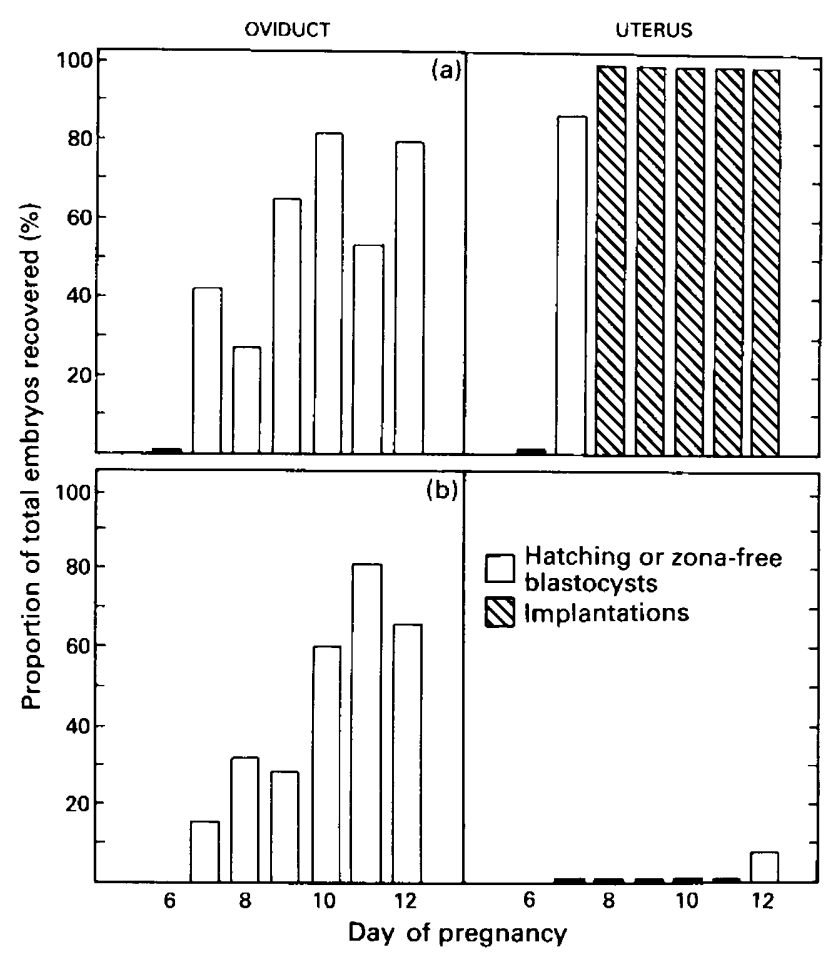

Fig. 1. The influence of oviducal and uterine environments on blastocyst hatching and implantation in non-lactating (a) and lactating (b) pregnant gerbils. Based on data presented in Table 1.

Fig. 2. Gerbil embryos recovered after oviducal ligation (a-d) or from intact females (e-i).

(a) Expanded, spherical, zona-intact blastocyst recovered from the ligated oviduct of a lactating female on Day $8 . \times 400$.

(b) Blastocyst with ruptured zona pellucida recovered from the ligated oviduct of a nonlactating female on Day 8. $\times 400$.

(c) Zona-free blastocysts recovered from the ligated oviduct of a non-lactating female on Day 11 (upper), and from a lactating female on Day 10 (lower). Both $\times 450$.

(d) Zona-intact elliptical blastocyst recovered on Day 8 from the ligated oviduct of a lactating female on Day 12. $\times 450$.

(e) Blastocyst with loosely attached zona pellucida in open oviducal lumen of a lactating female on Day $12 . \times 240$.

(f) Expanded, zona-free blastocyst in the oviducal lumen of a lactating female on Day 12. $\times 280$.

(g) Uterus of a lactating female on Day 12 with closely apposed luminal epithelia and a zona-intact blastocyst (see inset) in the antimesometrial part. $\times 70$, inset $\times 180$.

(h) Very compressed, zona-intact blastocyst in the antimesometrial part of the uterus of a lactating female on Day 12. $\times 350$.

(i) Compressed, zona-intact blastocyst in antimesometrial uterine crypt of a lactating female on Day 12. The open lumen most probably represents a shrinkage artefact due to fixation. Surface contour of the luminal epithelium on the right showing imprint of blastocyst from putative earlier closure. $\times 250$. 

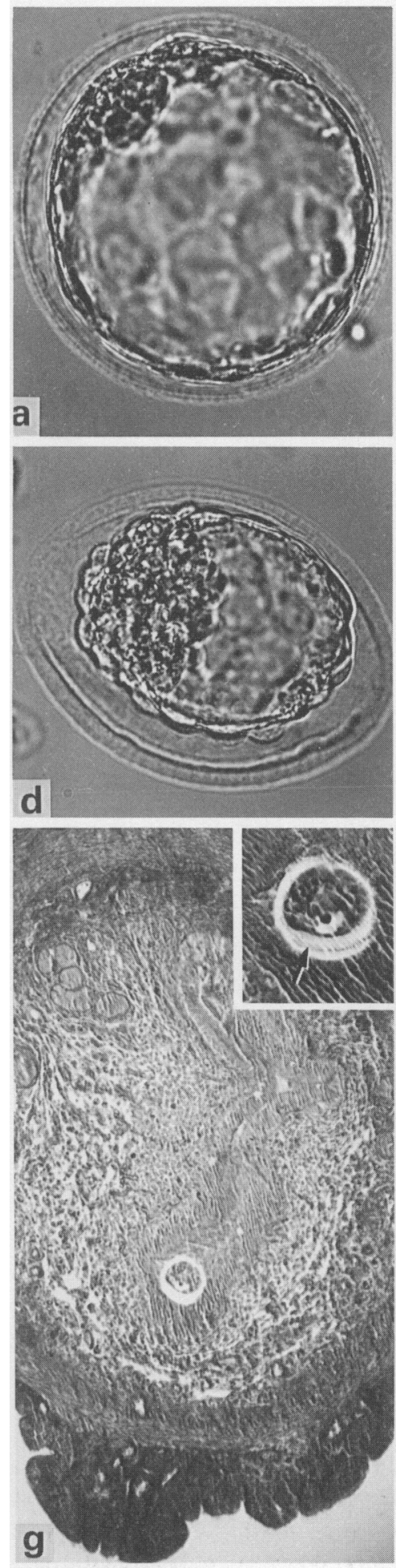
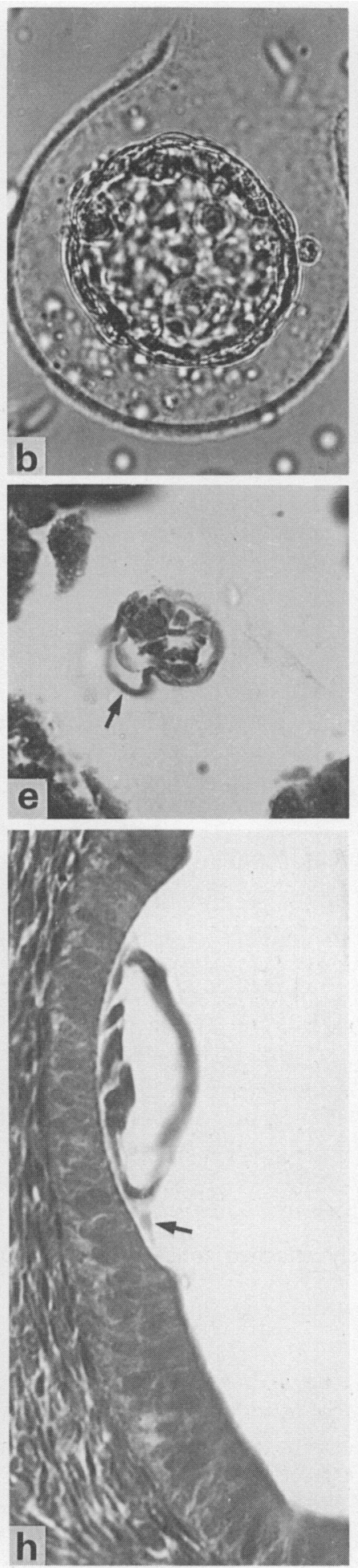
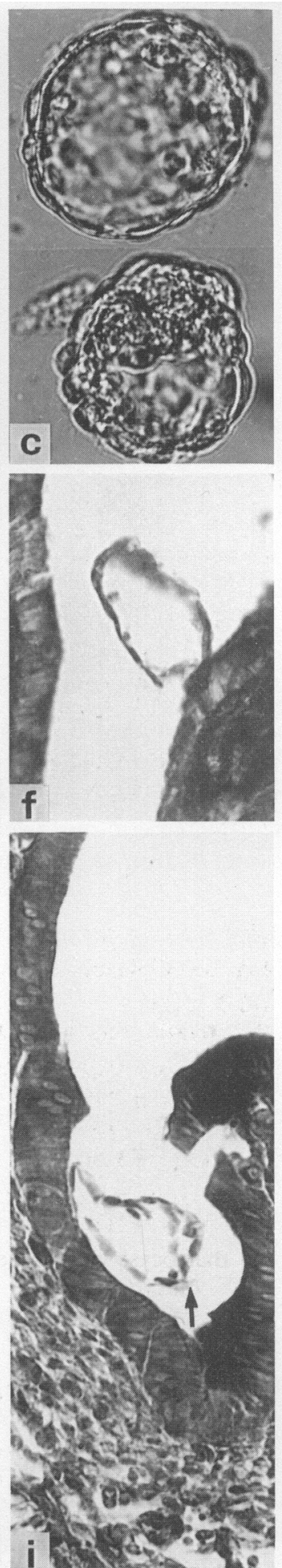
Table 2. The number of cells (mean \pm s.e.m.) present in blastocysts relative to the site and stage of development in non-lactating (a) and lactating (b) pregnant gerbils

\begin{tabular}{|c|c|c|c|c|c|c|}
\hline \multirow{2}{*}{\multicolumn{2}{|c|}{$\begin{array}{l}\text { Day } \\
\text { p.c. }\end{array}$}} & \multirow[b]{2}{*}{$\begin{array}{c}\text { No. of } \\
\text { \&q }\end{array}$} & \multicolumn{2}{|c|}{ Ligated oviduct } & \multicolumn{2}{|c|}{ Contralateral uterine horn } \\
\hline & & & $\begin{array}{c}\text { No. of } \\
\text { blastocysts }\end{array}$ & No. of cells & $\begin{array}{c}\text { No. of } \\
\text { blastocysts }\end{array}$ & No. of cells \\
\hline \multirow[t]{7}{*}{ (a) } & 6 & 3 & 10 & $40 \cdot 8 \pm 4 \cdot 3$ & 8 & $43 \cdot 2 \pm 5 \cdot 7$ \\
\hline & 7 & 5 & 10 & $77 \cdot 4 \pm 8.0$ & 4 & $78.0 \pm 5.9$ \\
\hline & 8 & 7 & 17 & $109 \cdot 1 \pm 6 \cdot 2$ & 一 $^{*}$ & - \\
\hline & 9 & 7 & 9 & $117.7 \pm 9.8$ & $\ldots *$ & - \\
\hline & 10 & 6 & 13 & $100 \cdot 4 \pm 3.4$ & - $^{*}$ & - \\
\hline & 11 & 8 & 12 & $103 \cdot 2 \pm 7 \cdot 5$ & 一 $^{*}$ & - \\
\hline & 12 & 5 & 10 & $99 \cdot 1 \pm 7 \cdot 7$ & 一 $^{*}$ & - \\
\hline \multirow[t]{6}{*}{ (b) } & 7 & 5 & 12 & $68 \cdot 0 \pm 6 \cdot 4$ & 11 & $56.8 \pm 3.6$ \\
\hline & 8 & 7 & 12 & $83 \cdot 3 \pm 7 \cdot 5$ & 13 & $78.2 \pm 4.8$ \\
\hline & 9 & 9 & 24 & $102 \cdot 1 \pm 3 \cdot 3$ & 14 & $99 \cdot 1 \pm 5 \cdot 2$ \\
\hline & 10 & 6 & 15 & $91 \cdot 3 \pm 4 \cdot 9$ & 14 & $101.0 \pm 3.6$ \\
\hline & I1 & 7 & 20 & $92.8 \pm 3.8$ & 13 & $99 \cdot 0 \pm 4 \cdot 4$ \\
\hline & 12 & 7 & 15 & $105 \cdot 2 \pm 10 \cdot 4$ & 14 & $90 \cdot 1 \pm 5 \cdot 1$ \\
\hline
\end{tabular}

*Implantations present after Day 7.

\section{Number of cells per blastocyst}

Cell counts made on 81 oviducal and 12 uterine blastocysts recovered from 41 non-lactating females on Days 6-12, and on 98 oviducal and 79 uterine blastocysts recovered from 41 lactating females on Days 7-12 are presented in Table 2. The three major blastocyst populations showed a similar increase in mean cell number up to Day 9 when $\sim 100$ cells were present. There was no apparent increase in cell number from Day 9 to 12 (see Table 2).

\section{Histological study of blastocysts in situ}

In the 6 lactating females examined on Day 12, $27 \mathrm{CL}$ were counted and $13(48 \%)$ embryos were observed in the ligated oviducts; $18 \mathrm{CL}$ were counted and 18 embryos $(100 \%)$ were observed in the contralateral uterine horns. Of the 13 oviducal embryos observed, 7 (54\%) were zona-intact, including 3 showing evidence of zona collapse following assumed earlier expansion, and 6 (46\%) were either hatching or zona-free (Fig. 2f). The majority of the embryos were lying freely within an open lumen (Fig. 2e), with the zona-intact ones in particular having an expanded spherical shape. It was possible to locate empty, collapsed zonae and often relate them within a few sections to a zonafree blastocyst. All of the 18 uterine blastocysts were zona-intact. Close apposition of the luminal epithelia was evident in some sections (Fig. $2 \mathrm{~g}$ ), and in the absence of uterine closure evidence was found suggesting an initial state of closure followed by tissue shrinkage during the period from autopsy to completion of fixation (Figs $2 \mathrm{~h} \& \mathrm{i}$ ).

\section{Discussion}

In the present study, embryos experimentally retained in the oviducts of non-lactating females developed normally and the zona was shed at the same time as those in the contralateral uterine horn, thereby indicating that 'uterine experience' is not essential for successful preimplantation development of the gerbil embryo. Although the gerbil blastocysts recovered from the ligated oviducts were morphologically similar to those described earlier for the mouse (Orsini \& McLaren, 
1967), the rate of loss of the zona was much slower in the present study. This may relate to species differences in the structure of the zona pellucida (Inoue \& Wolfe, 1975) and/or the deutoplasm of the blastocyst (Mehrotra, Einarsson \& Nilsson, 1981) giving species difference in the relative importance of intrinsic (blastocyst) and extrinsic (uterine) factors regarding zona shedding. This difference is also evident after culturing mouse and gerbil embryos in vitro, because although development of both types proceeds equally well, only the mouse blastocysts hatch readily (W. F. Rall \& M. L. Norris, unpublished observation). The wide variation in size of gerbil oviducal blastocysts together with the frequent occurrence of greatly expanded forms within thin, often cracked, zonae is in accord with the concept of internally generated, alternate expansion and contraction undergone by mouse blastocysts in vitro (Cole, 1967). This 'self hatching' (Mintz, 1970) is also believed to be the primary method of zona shedding in vivo (Orsini \& McLaren, 1967; Bergstrom, 1972).

Although the rate of cellular proliferation was similar in uterine and oviducal blastocysts from lactating females, and oviducal blastocysts from non-lactating females, blastocysts hatched in the oviducts at the same rate irrespective of the presence or absence of lactation, thereby indicating blastocyst autonomy within the maternal oviducal environment. A relalatively unchanging oviducal environment independent of ovarian steroid influence has been indicated in the rabbit (Adams, 1973; Beier, 1974).

The presence of empty zonae in the oviducts of non-lactating and lactating gerbils and their absence in the uteri of non-lactating females accords with the concept of uterine-specific zona-lytic factor expediting the internal hatching mechanism and subsequently effecting zona-dissolution (Orsini \& McLaren, 1967; McLaren, 1970). The zona-lytic effect of uterine fluids in mice treated with oestradiol and progesterone has been demonstrated in vitro (Hoversland \& Weitlauf, 1981) and in vivo (Hoversland \& Weitlauf, 1982). A result similar to the present oviducal findings for the gerbil has been obtained by Yasukawa \& Meyer (1966) for the uteri of rats in experimental delay, indicating the absence of the oestrogen-dependent zona-lytic factor.

The present results showing a similar rate of oviducal blastocyst development, onset and rate of zone shedding, irrespective of whether the contralateral uterine horn contains implantations or zona-intact blastocysts in delay, indicate the presence of a uterine-specific, oestrogen-negated inhibitory factor(s). In addition, the similar cell numbers found in the oviducal and uterine 'delayed' blastocysts indicate that differences in the rate of zona-shedding were not due to differences in the degree of maturation as indexed by cell numbers. These blastocysts also showed a pattern of cellular proliferation similar to that of mouse blastocysts during lactational and experimental delay (McLaren, 1968; Copp, 1978; Van Blerkom, Chavez \& Bell, 1979).

The absence of an inhibiting factor(s) in such environments as the oviduct, the uteri of nonlactating females and during culture in vitro would enable mature blastocysts to hatch by intrinsic activity, this process being expedited and synchronized in the uterus by an oestrogen-dependent zona-lytic factor. Uterine inhibition of blastocyst activity is believed to be due to the presence of a specific molecular component of uterine fluid in the rat (Psychoyos \& Bitton-Casimiri, 1969; Psychoyos, 1973) and the mouse (Weitlauf, 1976; Aitken, 1977), or to the imposition of environmental constraints made possible by the interdependence of macromolecules, essential ions and metabolites (Surani \& Fishel, 1981). There is a significant increase in oestrogen-dependent, intraluminal uterine protein before zona-shedding in the gerbil (Norris, 1979). In the mouse, this secretion is thought to stimulate the blastocyst to overcome the effects of the putative inhibitor (O'Neill \& Quinn, 1983), or to dissipate the effect of the inhibitor (Camus, Lejeune \& Leroy, 1979). An interplay of inhibitory and stimulatory factors is possible, and indeed may be necessary and compatible for a full explanation (Mintz, 1970; Weitlauf \& Kiessling, 1981).

The present histological results confirmed that loss of the zonae pellucidae from blastocysts in the ligated oviducts was not due to a manipulative artefact, and further showed that during lactational delay the oviducal lumen remains open whereas the uterus undergoes luminal closure. These features correlate well with the general characteristics of blastocysts recovered from these 
two regions of the reproductive tract. The observed zona-retention by gerbil 'delayed' blastocysts is considered to be due to putative inhibitor(s) in the uterine fluid, or to constriction via close apposition of uterine epithelia, these factors acting either singly or in combination. The mouse also shows uterine closure during delay and although the blastocysts are zona-free for most of the delay period, there is in fact a slight, but significant extension of the period of zona retention (McLaren, 1967; Orsini \& McLaren, 1967). The slower rate of zona removal observed in the oviducts, 'delay' uteri and during culture in vitro of gerbil compared with mouse blastocysts could be due to inherent species differences in metabolic or motional activity of the blastocyst, or to a greater reliance on an oestrogen-dependent, extrinsic lytic factor(s) to effect zona-loss in the gerbil.

I thank Mr D. E. Walters, AFRC Statistics Group, Department of Applied Biology, University of Cambridge, for carrying out the statistical analysis.

\section{References}

Adams, C.E. (1973) The development of rabbit eggs in the ligated oviduct and their viability after re-transfer to recipient rabbits. J. Embryol. exp. Morph. 29, 133-144.

Aitken, R.J. (1977) The culture of mouse blastocysts in the presence of uterine flushings collected during normal pregnancy, delayed implantation and prooestrus. J. Embryol. exp. Morph. 41, 295-300.

Beier, H.M. (1974) Oviducal and uterine fluids. $J$. Reprod. Fert. 37, 221-237.

Bergstrom, S. (1972) Shedding of the zona pellucida of the mouse blastocyst in normal pregnancy. J. Reprod. Fert. 31, 275-277.

Camus, M., Lejeune, B. \& Leroy, F. (1979) Induction of implantation in the rat by intraperitoneal injection of actinomycin D. Biol. Reprod. 20, 1115-1118.

Cole, R.J. (1967) Cinemicrographic observations on the trophoblast and zona pellucida of the mouse blastocyst. J. Embryol. exp. Morph. 17, 481-490.

Copp, A.J. (1978) Interaction between inner cell mass and trophectoderm of the mouse blastocyst. 1. A study of cellular proliferation. J. Embryol. exp. Morph. 48, 109-125.

Dulbecco, R. \& Vogt, M. (1954) Plaque formation and isolation of pure lines with poliomyelitis viruses. $J$. exp. Med. 99, 167-199.

Hoversland, R.C. \& Weitlauf, M. (1981) Lysis of the zona pellucida and attachment of embryos to the uterine epithelium in ovariectomized mice treated with oestradiol-17 $\beta$ and progesterone. J. Reprod. Fert. 62 , $111-116$.

Hoversland, R.C. \& Weitlauf, H.M. (1982) In-vitro zonalytic activity in uterine fluid from ovariectomized mice treated with oestradiol- $17 \beta$ and progesterone. $J$. Reprod. Fert. 64, 223-226.

Inoue, M. \& Wolfe, D.P. (1975) Comparative solubility properties of rat and hamster zonae pellucidae. Biol. Reprod. 12, 535-540.

McLaren, A. (1967) Delayed loss of the zona pellucida from blastocysts of suckling mice. J. Reprod. Fert. 14, $159-162$.

McLaren, A. (1968) A study of blastocysts during delay and subsequent implantation in lactating mice. $J$. Endocr. 42, 453-464.

McLaren, A. (1970) The fate of the zona pellucida in mice. J. Embryol. exp. Morph. 23, 1-19.
McLaren, A. (1973) Blastocyst activation. In The Regulation of Mammalian Reproduction, pp. 321-328. Eds S. J. Segal, R. Crozier, P. A. Corfman \& P. G. Condliffe. Thomas, Springfield.

Meckley, P.E. \& Ginther, O.J. (1972) Delayed nidation in lactating mongolian gerbils. Am. J. vet. Res. 33, 1247-1251.

Mehrotra, P.K., Einarsson, B. \& Nilsson, B.O. (1981) Ultrastructure of the yolk substance in preimplantation embryos of the gerbil. Uppsala J. med. sci.86, 233-236.

Mintz, B. (1970) Control of embryo implantation and survival. Adv. Biosci. 6, 317-342.

Norris, M.L. (1979) Studies on reproduction in the female Mongolian gerbil, Meriones unguiculatus, with particular reference to ovum implantation. $\mathrm{Ph}$. D. thesis, C.N.A.A.

Norris, M.L. \& Adams, C.E. (1971) Delayed implantation in the Mongolian gerbil, Meriones unguiculatus. J. Reprod. Fert. 27, 486-487.

Norris, M.L. \& Adams, C.E. (1981) Mating post partum and length of gestation in the Mongolian gerbil (Meriones unguiculatus). Lab. Anim. 15, 189-191.

Norris, M.L. \& Rall, W.F. (1983) Egg transfer in the Mongolian gerbil (Meriones unguiculatus) during lactational delay of implantation. J. Reprod. Fert. 68, 123-128.

O'Neill, C.O. \& Quinn, P. (1983) Inhibitory influence of uterine secretions on mouse blastocysts decreases at the time of blastocyst activation. J. Reprod. Fert. 68, 269-274.

Orsini, M.W. (1962) Technique of preparation, study and photography of benzyl benzoate cleared material for embryological studies. J. Reprod. Fert. 3, 283-287.

Orsini, M.W. \& McLaren, A. (1967) Loss of the zona pellucida in mice, and the effect of tubal ligation and ovariectomy. J. Reprod. Fert. 13, 485-499.

Psychoyos, A. (1973) Hormonal control of ovo implantation. Vitams Horm. 31, 201-256.

Psychoyos, A. \& Bitton-Casimiri, V. (1969) Caption in vitro d'un précurseur d'acide ribonucléique (ARN) (uridine- $5-{ }^{3} \mathrm{H}$ ) par le blastocyste du rat: différence entre blastocyste hormaux et blastocyste en diapause. C. r. hebd. Séanc. Acad. Sci., Paris D 268, 188-192.

Surani, M.A.H. \& Fishel, S.B. (1981) Embryonic and 
uterine factors in delayed implantation in rodents. $J$. Reprod. Fert., Suppl. 29, 159-172.

Tarkowski, A.K. (1966) An air-drying method for chromosome preparations from mouse eggs. Cytogenetics 5, $394-400$.

Van Blerkom, J., Chavez, D.J. \& Bell, H. (1979) Molecular and cellular aspects of facultative delayed implantation in the mouse. In Maternal Recognition of Pregnancy (Ciba Fdn Symp. No. 64), pp. 141-163. Ed. J. Whelan. Elsevier/Excerpta Medica/North Holland, Amsterdam.

Weitlauf, H.M. (1976) Effect of uterine flushings on RNA synthesis by implanting and delayed implanting mouse blastocysts in vitro. Biol. Reprod. 14, $566-571$.
Weitlauf, H.M. \& Kiessling, A.A. (1981) Activation of 'delayed implanting' mouse embryos in vitro. $J$. Reprod. Fert., Suppl. 29, 191-202.

Wu, J.T. (1975) Time of implantation in the Mongolian gerbil (Meriones unguiculatus) and its hormonal requirements. Biol. Reprod. 13, 298-303.

Yasukawa, J.J. \& Meyer, R.K. (1966) Effect of progesterone and oestrone on the preimplantation and implantation stages of embryo development in the rat. J. Reprod. Fert. 11, 245-255.

Received 20 May 1985 